\title{
Training mode analysis of orbit traffic signal control and professional talent Based on the "work-integrated learning, cooperation between colleges"
}

\author{
Haiyan Wang ${ }^{a}$, Fanwei Meng ${ }^{b}$ and Congbo Luo ${ }^{c}$ \\ Changchun University of science and technology, Changchun, 130000, China \\ a13742883@qq.com, b594661212@qq.com, c43403188@qq.com
}

\begin{abstract}
With China's high-speed railway and inter-city railway and urban light rail and the rapid development of subway, the growing demand for talent demand is higher and higher, especially the requirement of practical ability. To reform the traditional teaching mode, to achieve "university-enterprise cooperation and work-integrated learning" personnel training mode is an effective way to solve this problem. In this paper, according to the department of orbit traffic signal control and the actual situation and characteristics of the exploration of the reform mode of talent training scheme.
\end{abstract}

Keywords: Rail transit; Cultivation of talents; University-enterprise cooperation; Teaching mode;

Work-integrated learning.

\section{Introduction}

With the rapid development of China's economy and the expanding of the city, more and more in the second and third line of urban rail transportation has reached the golden age, successively into the age of "light rail" subway era ", at the same time, the demand for urban rail transit professionals quickly soared. Currently existing talent cultivation system not perfect and mature. Therefore, how to cultivate high professional quality, strong professional skills to meet the requirements of enterprise talents, become all orbit traffic signal professional colleges and universities are faced with the problem. "Work-integrated learning, cooperation between colleges" education mode is run by the local independent bachelor orbit traffic signal control and the only way to cultivate high-quality talents with high skill.

\section{The necessity of "work-integrated learning, university-enterprise cooperation"}

The practice of the current domestic urban rail transit from personnel of course of ability and graduate level does not match. Enterprise for graduates has considerable practical and hands-on ability of operation, cultivate the talents in colleges and universities majority theoretical content of learning. Therefore, disconnect between higher demands for talent. The introduction of "work-integrated learning, cooperation between colleges" talent cultivation model, better realize the talent perfect docking of school and enterprise. University-enterprise cooperation is refers to the university and the related companies, professional construction, curriculum system, faculty construction, practice condition of the optimization of multi-level and comprehensive cooperation. With the aid of resource advantages inherent in the training venue, the organic combination of classroom teaching and practice, the organic combination of the school education and training, and runs through the whole four years in the process of the cultivation of the student. "Work-integrated learning, university-enterprise cooperation" is the theme of the personnel training mode, the students of class teaching with the practical work of complementary supplement each other, so that the students in the classroom to the theoretical knowledge and got some vocational training, gain experience in practice, for the future work better development laid a solid foundation. To sum up, teaching model of "work-integrated learning, university-enterprise cooperation" is the collection of both schools and enterprises the advantage of a new type of teaching mode, cultivate the talents is conform to the requirements of the national ministry of education to the university and meet the 
requirements of enterprise ability to graduates of choose and employ persons, culture is a kind of principle of combining the compound applied talents.

\section{The main characteristic of "work-integrated learning}

Cooperation between colleges" Orbit traffic signal control and professional training mode of "university-enterprise cooperation and work-integrated learning" is a common culture theory by schools and related enterprise cooperation, skilled and applied in talent. The training mode has the following characteristics: 1) the theory teaching and practice operation. My school orientation for applied undergraduate colleges, orbit traffic signal control and professional talent training focuses on: on the basis of the theory learning in cultivating in the front line in the production of real practical operation ability and solve the question ability. Is a must to achieve the ability to make the students in the real work environment training operation, as far as possible in the enterprise of the real work environment for learning and training? In the future, especially rail traffic signal control and professional, for a line of railway signal control, diagnosis, maintenance and operation of locomotive. So only limited to the book content, don't go to practice is not enough. Book knowledge and site construction work experience together, lead the students to participate in the enterprise, social communication, obtaining knowledge. In the railway signal detection and diagnosis of learning knowledge, improve ability in the railway engineering project design, the scene of the train operation training environment is the most effective exercise. 2) Practice and teaching supplement each other. Classroom is a place of students learning theory knowledge, is to improve the experimental skills of laboratory, teaching in colleges and universities are mainly concentrated in the classroom and laboratory, so the lack of the ability to work site training, lack of productive practice in place, especially rail passenger cars and other large facilities and equipment. Enterprises in order to obtain high skills inter-disciplinary talent, hope and cooperation in running schools with zero distance of the college students internship program. A bit of an enterprise is with production line and the construction site, the training of the students can "live". To solve the problem of the practice base of colleges and universities. And hire firms experienced technicians and engineers at the scene of the production guide students in learning and training, training teachers in colleges and universities to solve the problem. 3) Employment direction is accurate. Through the training mode of "work-integrated learning, cooperation between colleges and schools can contact in advance enterprise, the enterprise standard of choose and employ persons, in order to target the cultivation of the students. Enterprises, concrete practice, to participate in the internship and internship process in system analysis, adjust the orbit traffic signal control and professional curriculum system, curriculum setting, curriculum content, the talent training scheme according to requirements. At the same time, students know early contact with enterprises, enterprises can accurately locate the difference between their power and position requirements. In training and classroom activities to improve their weak links. This kind of cooperation in running schools with the enterprise, reform the curriculum system and restructuring course content of teaching mode, and cultivate the talents will be in an impregnable position in the competition for jobs.

\section{4. "Work-integrated learning, cooperation between higher vocational colleges and the construction of personnel training mode}

\section{1 " $3+1$ " training mode reform}

Department of orbit traffic signal and control on the basis of original traditional talent training scheme reform of " $3+1$ " in the form of the talent training scheme. The so-called " $3+1$ " is the theory of learning time for three years, a senior throughout the year all to participate in various kinds of internship. Internship time increases, achieved the effect of strengthening practice ability. The specific teaching time arrangement is as follows table 1, can be seen from the table in the practice proportion increase, the specific arrangement such as table 2 . 
Table 1 teaching activity schedule

\begin{tabular}{|c|c|c|c|c|c|c|c|c|c|}
\hline \multirow{2}{*}{ project } & \multicolumn{7}{|c|}{ semester } & \multirow{2}{*}{ summation } \\
\cline { 2 - 10 } & 1 & 2 & 3 & 4 & 5 & 6 & 7 & 8 & 140 \\
\hline $\begin{array}{c}\text { The total number of weeks of } \\
\text { teaching }\end{array}$ & 16 & 18 & 17 & 18 & 17 & 18 & 18 & 18 & 99 \\
\hline Theory teaching & 12 & 16 & 14 & 16 & 15 & 17 & 9 & & 7 \\
\hline $\begin{array}{c}\text { 99Practice teaching } \\
\text { (The teaching practice) }\end{array}$ & & 1 & 2 & 1 & 2 & & 1 & & 4 \\
\hline Curriculum design & 1 & & 1 & 1 & & 1 & & & 3 \\
\hline Military training & 3 & & & & & & & & 6 \\
\hline The test & 1 & 1 & 1 & 1 & 1 & 1 & & & 7 \\
\hline motor & 1 & 1 & 1 & 1 & 1 & 1 & 1 & & $1(1)$ \\
\hline $\begin{array}{c}\text { The entrance, } \\
\text { graduate education }\end{array}$ & $(1)$ & & & & & & & 1 & 1 \\
\hline labor & & 1 & & & & & & & 10 \\
\hline $\begin{array}{c}\text { Graduation thesis } \\
\text { (Graduation design) }\end{array}$ & & & & & & & 8 & 7 & 15 \\
\hline $\begin{array}{c}\text { Graduation practice } \\
\text { (The production practice) }\end{array}$ & 7 & 6 & 7 & 6 & 7 & 6 & 7 & --- & 46 \\
\hline During the holiday & $25(1)$ & 26 & 26 & 26 & 26 & 26 & 26 & 18 & $199(1)$ \\
\hline total & & & & & & & 10 & 10 \\
\hline
\end{tabular}

Table 2 practice teaching process

\begin{tabular}{|c|c|c|c|c|c|c|}
\hline \multirow[b]{2}{*}{ Practice type } & \multirow[b]{2}{*}{$\begin{array}{l}\text { Course } \\
\text { number }\end{array}$} & \multirow[b]{2}{*}{ Practice the project name } & \multirow[b]{2}{*}{ credits } & \multicolumn{2}{|c|}{ weeks } & \multirow[b]{2}{*}{ semester } \\
\hline & & & & $\begin{array}{l}\text { Inside } \\
\text { the } \\
\text { school }\end{array}$ & $\begin{array}{l}\text { Outside } \\
\text { the school }\end{array}$ & \\
\hline \multirow{4}{*}{ Curriculum design } & 01060119 & C program design & 1 & 1 & & 1 \\
\hline & 01060219 & Analog electronic technology & 1 & 1 & & 3 \\
\hline & 01060319 & Digital electronic technology & 1 & 1 & & 4 \\
\hline & 01060419 & $\begin{array}{l}\text { Electrical control technology } \\
\text { and PLC applications }\end{array}$ & 1 & 1 & & 6 \\
\hline \multirow{6}{*}{ training } & 01060619 & Metalworking practice & 1 & 1 & & 2 \\
\hline & 01060719 & Electro technical practice & 1 & 1 & & 3 \\
\hline & 01060819 & $\begin{array}{l}\text { Communications equipment } \\
\text { operation and maintenance }\end{array}$ & 1 & & 1 & 5 \\
\hline & 01060919 & $\begin{array}{l}\text { Signal system maintenance } \\
\text { training }\end{array}$ & 1 & & 11 & 4 \\
\hline & 01061019 & $\begin{array}{l}\text { Urban rail transit power } \\
\text { supply system simulation } \\
\text { training }\end{array}$ & 1 & & 1 & 5 \\
\hline & 01061119 & $\begin{array}{l}\text { Rail transit operation } \\
\text { management practice }\end{array}$ & 1 & & 1 & 7 \\
\hline internship & 01061219 & $\begin{array}{l}\text { High-speed rail, urban rail and } \\
\text { bus tour }\end{array}$ & 1 & & 1 & 3 \\
\hline Military training & 00142119 & $\begin{array}{l}\text { Military training, military } \\
\text { theory) }\end{array}$ & 3 & 3 & & 1 \\
\hline labor & 00162219 & labor & 1 & 1 & & 2 \\
\hline Graduationpractice & 00002319 & $\begin{array}{l}\text { Graduation practice (field } \\
\text { work) }\end{array}$ & 15 & & 15 & $7-8$ \\
\hline $\begin{array}{l}\text { (design) graduation } \\
\text { thesis }\end{array}$ & 00002429 & Graduation design (paper) & 10 & 10 & & 8 \\
\hline \multicolumn{3}{|c|}{ amount to } & 40 & 20 & 20 & --- \\
\hline
\end{tabular}

Orbit traffic signal control and professional practice is divided into three levels. First of all, the first term in senior one to five weeks, the school training the teacher organizes the student to professional training room in the school comprehensive training program. Second, the school after 
the training arrangement to send students after graduation thesis topic into the enterprise training, practice; Practice has two modes, one for the field work, refers to an enterprise that learn internship arrangements specific internship, to participate in the orbit of real signal detection, diagnosis and maintenance of concrete work. Dedicated to guide the practice of teacher and student exchanges and communication. In the internship enterprise formal company worker equal pay for equal work. The field work of the unit with Changchun faw, China north car group, and a number of units in Shenyang railway bureau. Another for training practice. This kind of practice is and the related training institutions of cooperation in running schools, establish training laboratory in the school, the students in secondary special training. This kind of training approaches for training more, good training agreement with the enterprise first, and then targeted training to the student, direct access to relevant enterprises work after the training. Finally, after the practice outside of the last half of the semester senior students decentralized and centralized combination of graduation practice at the same time to complete the graduation design, writing essays.

\subsection{The construction of teachers' team.}

Because of the rail transit signal and control specialty is emerging in recent years, and is a new specialty in our school. So the teachers' level is relatively weak. In order to better adapt to the teaching model of "work-integrated learning, cooperation between colleges", the key to the construction of "double division type" high-quality teachers' team. Not only have profound theoretical knowledge, have strong ability of practice production. Solid theory foundation of basic skills of university teachers, mechanic manufacture experience, the two complement each other, forming conform to the "work-integrated learning, cooperation between colleges" teaching team. Therefore, rail transit signal and control to enterprise part-time professional teachers, increase practical ability in normal production and operation, at the same time employ technical backbone industry enterprises as practice skills classes' part-time teachers, employ internships enterprise senior technician as practical skills class and field work, the main teachers, has its own experimental teachers in charge of class. Study and communication between the teacher and focus on improve its full-time teachers' practical teaching ability.

\subsection{Construction of teaching experiment training conditions.}

On the basis of basic ability training, improve professional ability and professional ability request, according to the professional training, special skills training base, professional and comprehensive training three levels, build rail traffic signals/sand table simulation training room, track traffic signal control laboratory, microcomputer chain training rooms, provides students with the school experiment and training venues. For enterprises as a platform, establishing and perfecting orbit traffic signal control and professional practice teaching management system. To develop the outside school practice bases, to everyone who graduates can finish one year's internship program.

\section{Conclusion}

"Work-integrated learning, university-enterprise cooperation" training mode is orbit traffic signal control and the important direction of reform. In combination with the practical situation of orbit traffic signal control and professional, further raise awareness, and actively explore, emancipate the mind, bold practice, actively explore the new personnel training mode, to cultivate high-quality skilled compound applied talents, make greater contribution.

\section{Acknowledgments}

This work was 2015 vocational education and adult education in Jilin province department of education research project supported by the teaching reform. Project approval no. : 2015 zcy309. 


\section{References}

[1] C-ray-z Liu Yanlin. Cooperation between higher vocational colleges and the mode of high vocational education practice curriculum plan to explore - environment classes, for example [J]. Journal of Shenzhen institute of information technology, 2013, 2013:47-50.

[2] Zhang Hong. Explore the "work-integrated learning and cooperation between higher vocational colleges to cultivate professional talents $[\mathrm{J}]$. Chinese science and education innovation Tribune, 2013, 31:4.

[3] Ya-ming Wang. Our country secondary vocational university-enterprise cooperation research review [J]. Journal of continuing education research, 2013, 10:37, 39.

[4] Xiao Jing. Vestibule school "work-integrated learning" cultivation mode of practice research [D]. Hunan University, 2013.

[5] Li-ling Hu. Co-operative personnel training mode of higher vocational education research [D]. Fujian normal university, 2010.

[6] Becky. $\mathrm{N}$ the metro rail transit based on university-enterprise cooperation professional personnel training mode research [D]. Dalian maritime university, 2012.

[7] Fang Daichun. Higher vocational university-enterprise cooperation " $2+1 "$ training mode of practice research [D]. East China normal university, 2008. 